' ' ' دانش آموخته كارشناسى ارشد، مركز تحقيقات راه، مسكن و شهرسازى، (h.fasihi@ bhrc.ac.ir)

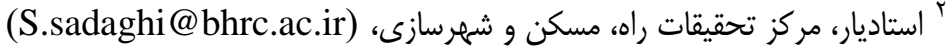

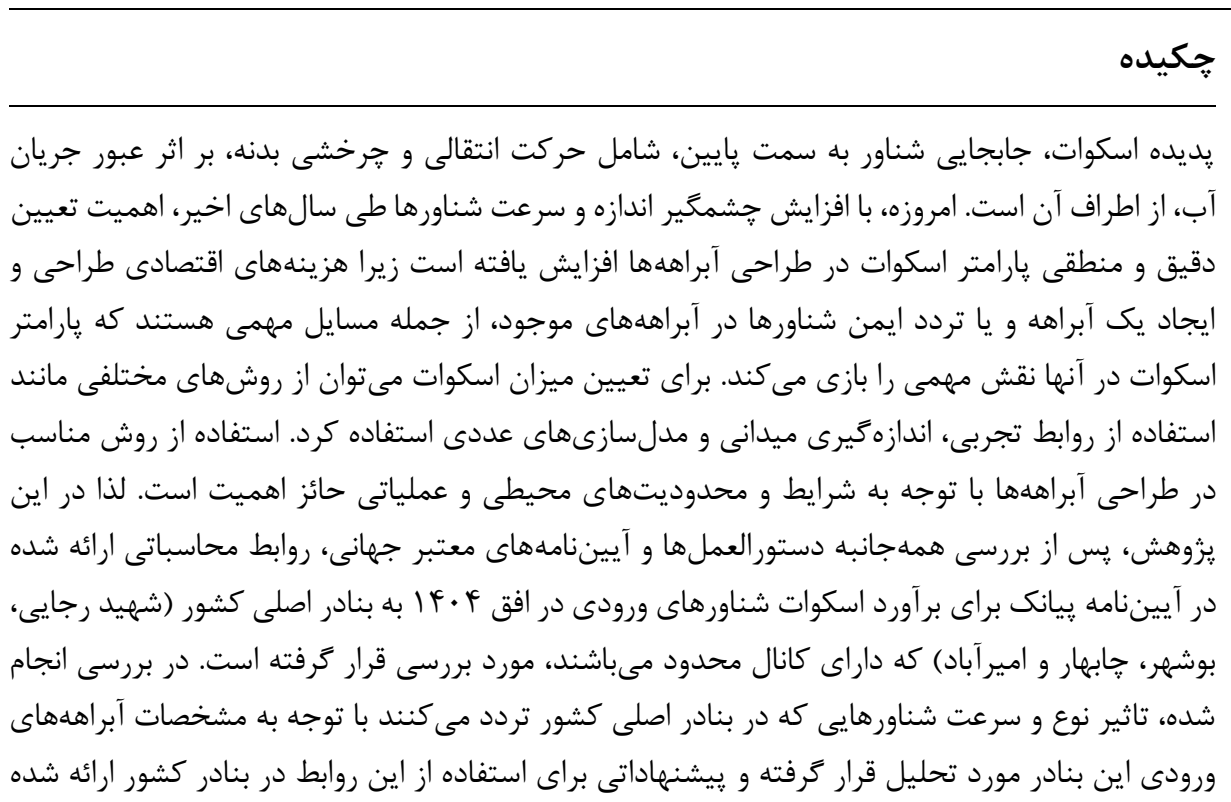

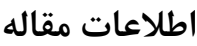

تاريخجه مقاله:

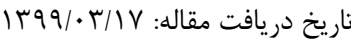

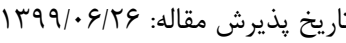

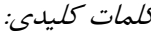

سكوات

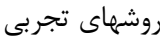

بنادر ايران

\title{
Estimating the squat of different vessel types in the design of Iranian ports waterways using empirical relations
}

\author{
Hoda Fasihi Karami ${ }^{*}$, Seyedeh Masoome Sadaghi ${ }^{2}$ \\ 1* M.Sc. Grad, Road, Housing \& Urban Development Research Center; h.fasihi@bhrc.ac.ir \\ ${ }^{2}$, Assistant Professor, Road, Housing \& Urban Development Research Center; S.sadaghi@bhrc.ac.ir
}

\section{ARTICLE INFO}

Article History:

Received: 06 Jun. 2020

Accepted: 16 Sep. 2020

\section{Keywords:}

Squat

empirical relations

Iranian ports

\begin{abstract}
Squat is a steady downward displacement consisting of a translation and rotation due to the flow of water past the moving hull. Nowadays, with the considerable increases in the size and speed of ships, the importance of accurate determination of the squat parameter in the design of waterways has increased. Squat has an important role both in economic costs of design and construction of new waterways and safe movement of ships in existing waterways. Various methods can be used for squat estimation including empirical relations, laboratory test models and numerical modeling. In this paper, based on PIANC recommendations, different empirical formulas are used to estimate the squat of the incoming ships to some of the main ports of Iran on the horizon of 1404. Finally, by concluding the results, suggestions are given for calculating the squat of different vessel types in the design of Iranian ports waterways.
\end{abstract}




\section{r- ( - مبانى نظرى تحقيق}

|r-r- - بيشينه تحقيق

مطالعات بسيارى به منظور محاسبه حداكثر مقدار اسكوات كشتىها با ابعاد مختلف در موقعيتهاى كوناكون انجام شده است. اولين رابطه

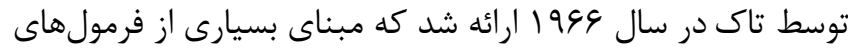

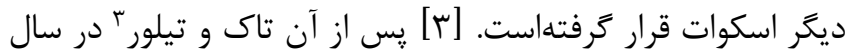
197 رابطهاى را براى محاسبه اسكوات در آبهاى كمبعمق ارائه

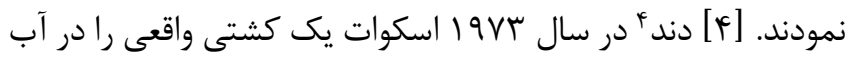

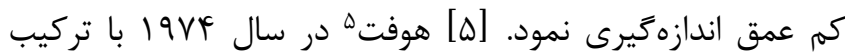
ضرايب مربوط به ميزان فرورفتكى و هرخش ارئه ائه شده در رابطه تاك، رابطه كاربردىترى را براى محاسبه اسكوات در كانالهاى

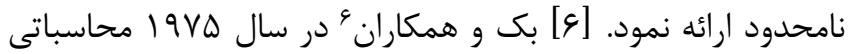

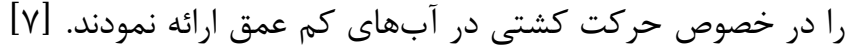
هوسكا' در سال I9V9 با اضافه كردن يك ضريب اصلاحى براى إي

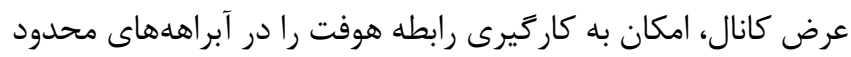

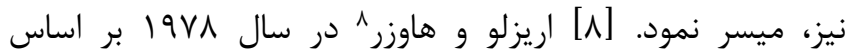
آزمايشات انجام شده در آبراهههاى نامحدود با عمق محدود، رابطهاى

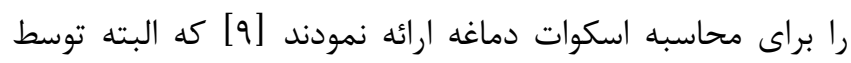

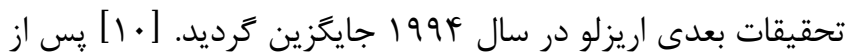

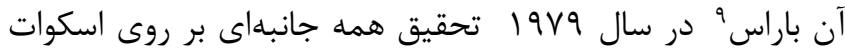

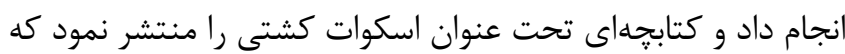

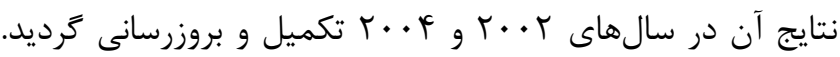

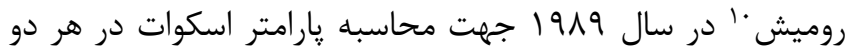

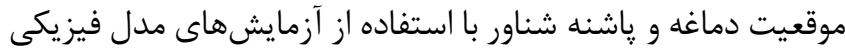

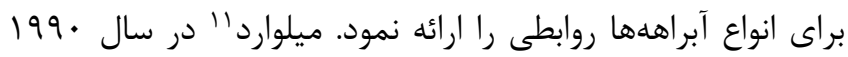
روشى را براى محاسبه اسكوات در آبهاى كم عمق انجام داد آداد

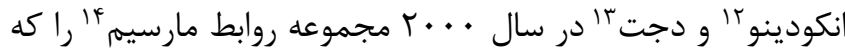
شامل .. فرمول جهت محاسبه حداكثر مقدار اسكوات، برمبناى

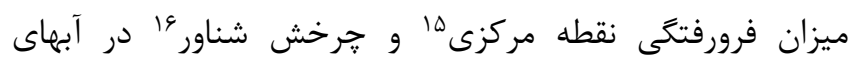
كمعمق، ارائه نمودند. اين روابط يكى از جامعترين و در عين حال حال

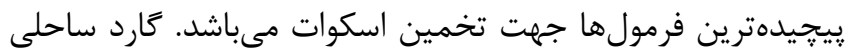

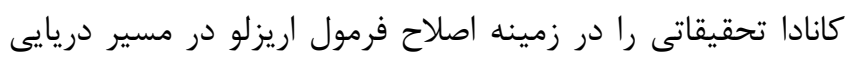

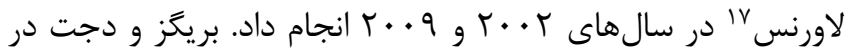

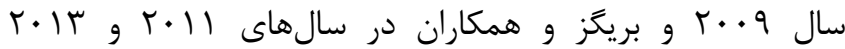
مقايسهاى ميان مقادير يِشبينى اسكوات با روابط مارسيهم و بيانك

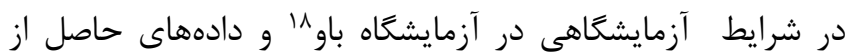
اندازمكيرىهاى انجام شده در كانال قاناما انجام دادند كه تطابق

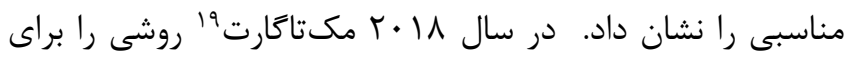
محاسبه اسكوات بر مبناى تئورى جريان يتانسيل رانكين ارائه كرد. تحقيقات متعدد محققين و متخصصين از سال 1994 تا كنون،

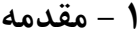

هنگامى كه كشتى يا شناورى با سرعت در يك مقطع محدود، مانند

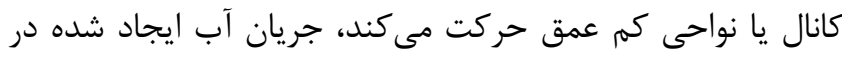

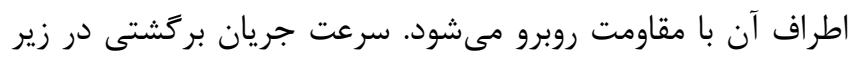
كشتى به علت كاهش سطح مقطع، زياد شده و سبب افت فشار

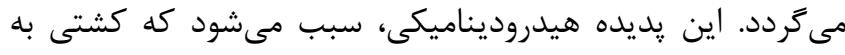

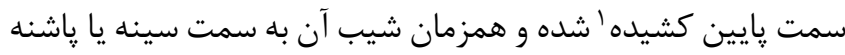
متمايل شود؟. مقدار فرورفتخى ديناميكى شناور در اثر اين يديده راني

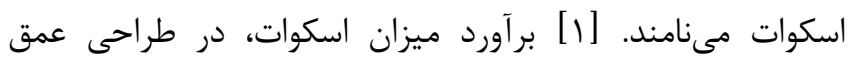

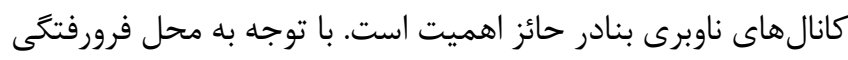
شناور، دو نوع اسكوات دماغه و ياشنه وجود دارد. از نظر تجربى، نادي، حداكثر مقدار اسكوات، در شناورهاى با سرعت بايين مانند شناورهاى تانكرى و فله، در دماغه و در كشتىهاى باريك و با سرعت بالا مانداند كشتىهاى مسافرى و كشتىهاى كانتينرى، حداكثر مقدار اسكوات

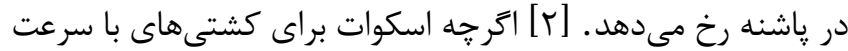

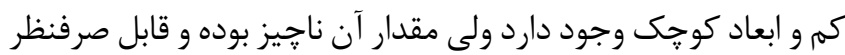
است، در مقابل در شناورهاى بزرگ، مقدار اسكوات قابل توجه بوده و مىتواند منجر به بروز مشكلاتى در ناوبرى و تردد ايمن شناورها

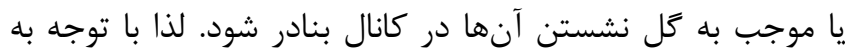

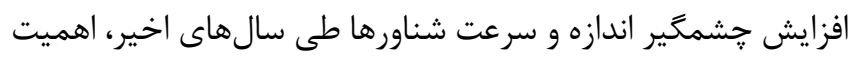
يديده اسكوات افزايش يافته است. براى تعيين ميزان اسكوات مىتوان از روشهاى مختلفى مانند استفاده از روابط تجربى، اندازهيرى برئي

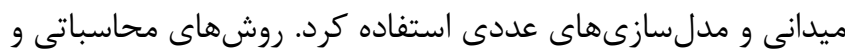

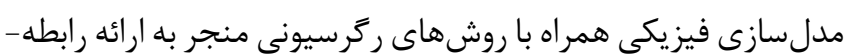
هاى تجربى كرديده است كه جايكاه مهمى در طراحى كانال ها دارند. همانطور كه استنباط مىشود، تعيين دقيق و منطقى يارامتر اسكوات

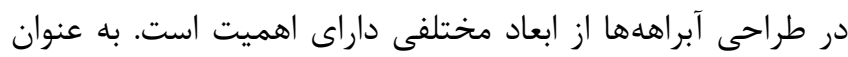

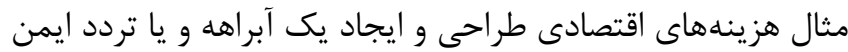

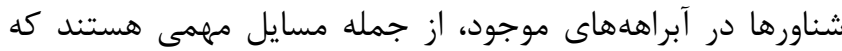

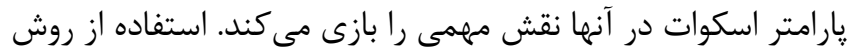

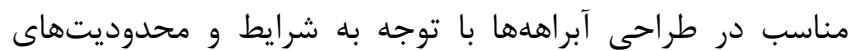

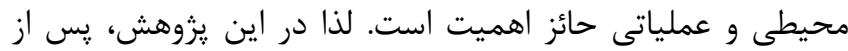

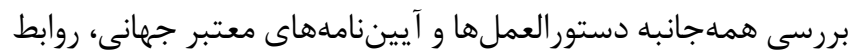

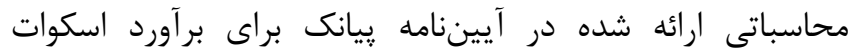

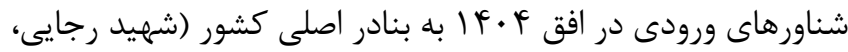
بوشهر، خابهار و اميرآباد) كه داراى كانال محدود مى باشنائد مورد

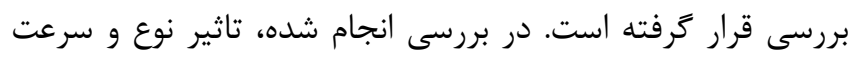

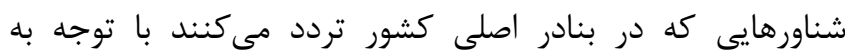

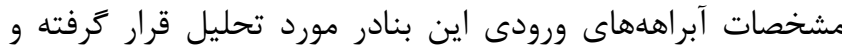
ي يشنهاداتى براى استفاده از اين روابط در بنادر كشور ارائه شده است. 
سابقه نشان داده است رابطه آيكورلز (•919) از عملكرد و نتايج

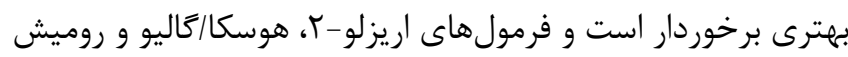

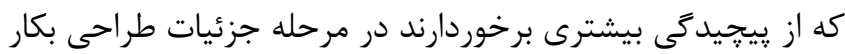

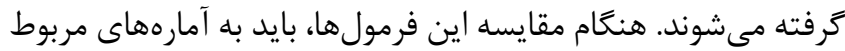
به حداقل، ميانكَين و حداكثر اسكوات توجه نمود كه حتما در بازه

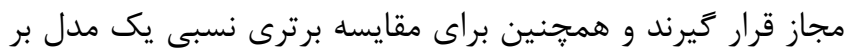

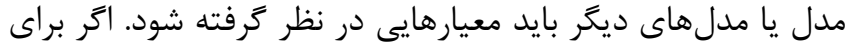
يروزه زمان و ميزان سرمايه معينى در نظر ترفته شده است، مى توان يك مدل فيزيكى يا عددى طراحى نمود و بر اساس نتايج حاصل از

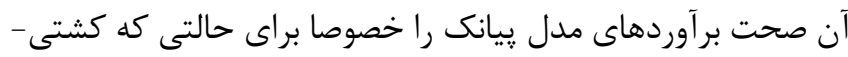
هاى جديد با ابعاد بزرى مد نظر است، اعتبارسنجى و تاييد كرد. همجنين ذكر شده است كه براى محاسبه بيشترين مقدار اسكوات

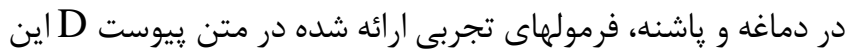
كزارش، بايد مورد بررسى دقيق و مقايسه قرار گيرند و در اين ميان

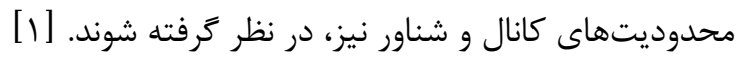

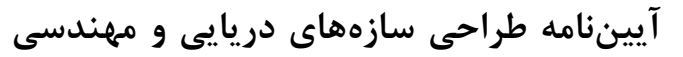

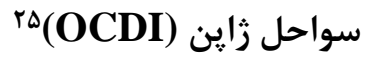

آيين نامه طراحى سازههاى دريايى و مهندسى سواحل زإين، استاندارد

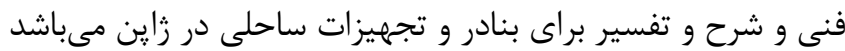

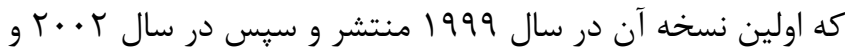

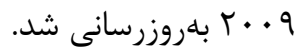
در نسخه Y +. T اين آيينامه، در تعيين عمق كانال ناوبرى اشاره مستقيم به مولفه اسكوات نكرده است ولى جهت تعيين حداقل فاصله كشتى تا بستر درياء؟ (كه شامل اسكوات نيز مىباشد)، كتابهاى استى نوشته شده توسط ياو و هوندا را به عنوان مرجع معرفى كرده است.

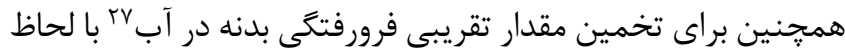

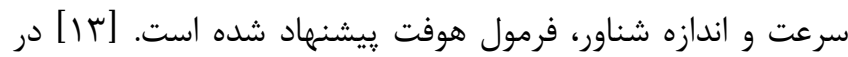

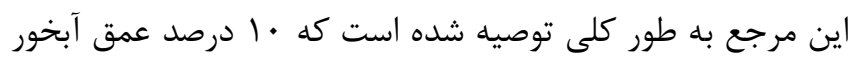
شناور به عنوان حداقل فاصله كف شناور تا بستر كانال در نظر كرفته

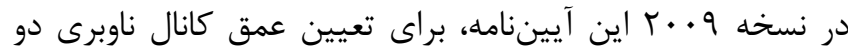
حالت در نظر كرفته شده است. حالت اول هنحامى است كه ابعاد شناور طرح، شرايط محيطى ناوبرى مانند آبوهوا، وضعيت دريا و سرعت كشتى مشخص نباشند. در اين حالت عمق كانال، ضريبى بين 1. 1 تا ז. ا حداكثر آبخور شناور طرح در آبهاى ساكن در نظر كرفته

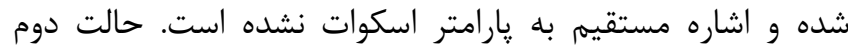
هنخامى است كه ابعاد شناور طرح و شرايط ناوبرى مانند آبوهوا،

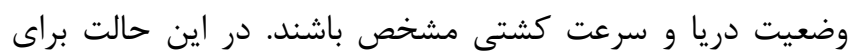

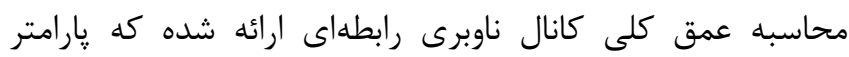

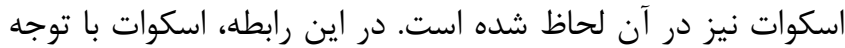

نشاندهنده اهميت تعيين دقيق مقدار اسكوات مىباشد كه اين

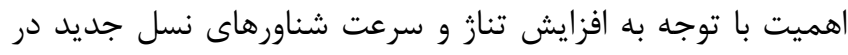

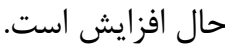

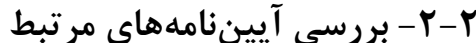

آيين نامها، راهنماها و دستور العملهاى تخصصى در هر حوزه، نتيجه يزوهشهاى كسترده متخصصان، متوليان و خبركان آن حوزه و

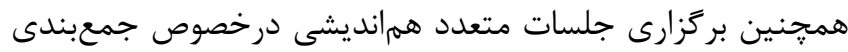
نتايج حاصله، بومىسازى آنها در كشور مربوطه و اخذ تصميمات نهايى مىباشند. بنابراين مىتوان آنها را بهعنوان مرجعى معتبر،

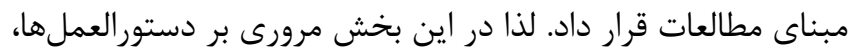
آييننامهها، راهنماها و ساير مراجع ملى و بينالمللى مرتبط و معتبر آنبر در خصوص محاسبه اسكوات در آبراهلها، انجام شده است.

\section{•آيين نامه طراحى بنادر و سازههاى دريايى ايران}

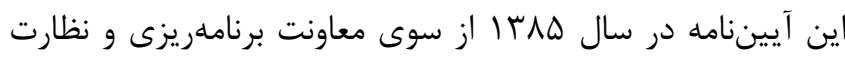
راهبردى رئيس جمهور به كليه دستكاههاى اجرايى، مهندسان مشاور

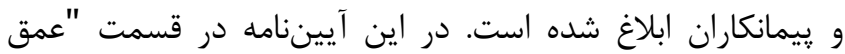

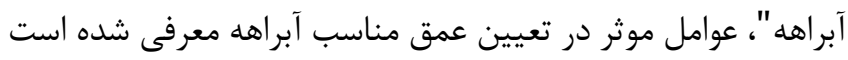
كه يكى از اين عوامل "اضافه عمق براى فروروى كشتى هنگام حركت

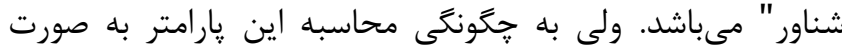
جداكانه اشارهاى نشده است. [11]

\section{• دستور العمل طراحى سازههاى ساحلى}

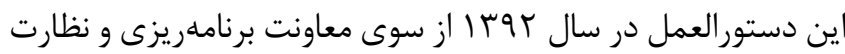
راهبردى رئيس جمهور به كليه دستخاههاى اجرايى، مهندسان مشاور و پيمانكاران ابلاغ شده است. در بخش ششم اين دستورالعمل تحت

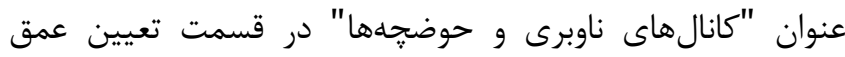

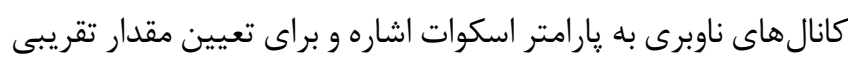

آن، ييشنهاد شده است كه از رابطه هوفت استفاده شود. [1 I]

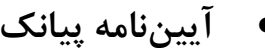

بيانك يك انجمن جهانى تخصصى مى باشد كه به عنوان قديمىترين

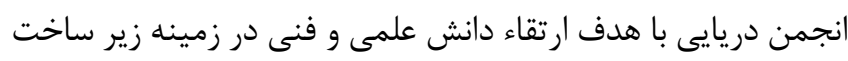

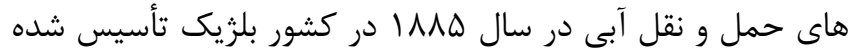

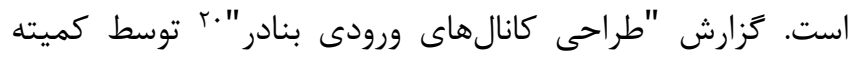

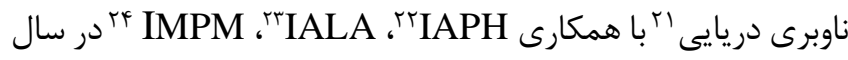

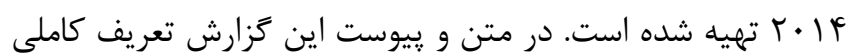
از اسكوات، اهميت اين يارامتر، عوامل موثر در تعيين آن و همجنين آندين روشهاى محاسبه آن به تفصيل توضيح داده شده است. بيانك

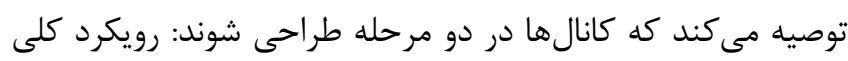
به طراحى و جزئيات طراحى. بطور كلى بر اساس اين آييننامه، براى

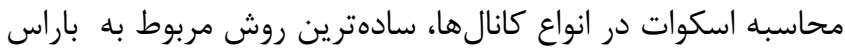

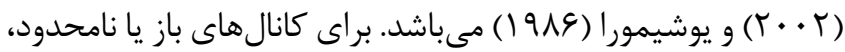


است. دادهها و اطلاعات مربوط به مشخصات كانال بندر، بر اساس نقشه هيدروكرافى هر بندر استخراج شده كه با توجه به اينكه عمق إنق

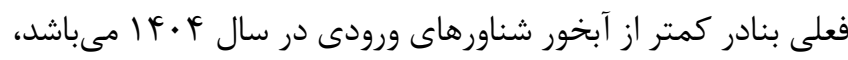
عمق كانال، ارتفاع و شيب ترانشه با استفاده از نظرات كارشناسيى محاسبه و تخمين زده شده است. با استفاده از دادههاى مذكور، مقدار

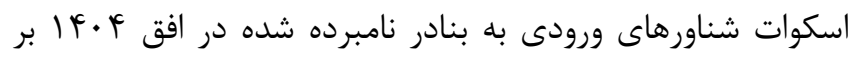
اساس رابطههاى تجربى ذكر شده در آييننامه پِيانك محاسبه شده است. (لازم به ذكر است به جز رابطه باراس در كشتىهائ كائ كانتينرى، تمامى روابط استفاده شده مربوط به محاسبه اسكوات دماغه شناورها

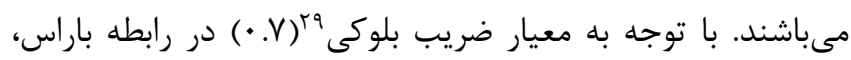

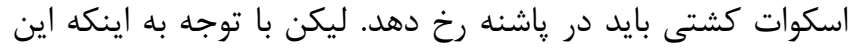
مقدار در شناورهاى كانتينرى نزديك به V. • مىباشد، انتظار مىرود

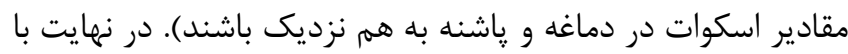

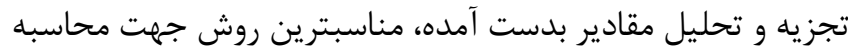
اسكوات در كانالهاى محدود به تفكيك نوع شناور يیشنهاد شده

شده است.

\section{F- محاسبه اسكوات در برخى بنادر اصلى كشور}

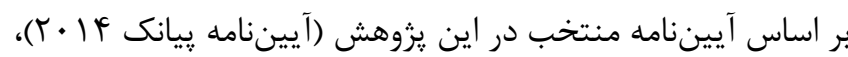

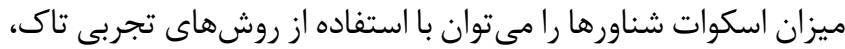
هوسكا/ كاليو، باراس، اريزلو، روميش، ايكورلز و يوشيمورا ، محاسبه

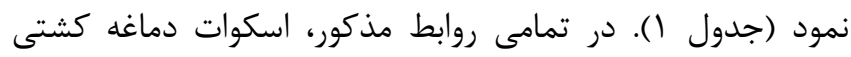

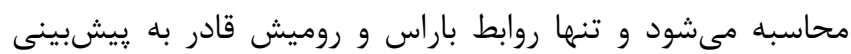
اسكوات ياشنه كشتى نيز مىباشند. در رابطه روميش دو فرمول جداكانه براى محاسبه اسكوات دماغه و پاشنه ارائه شده است. ليكن

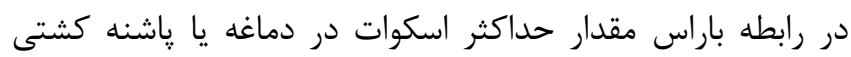

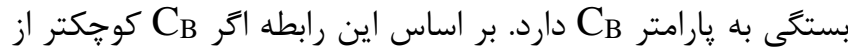

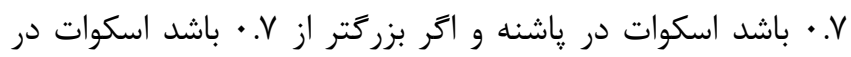

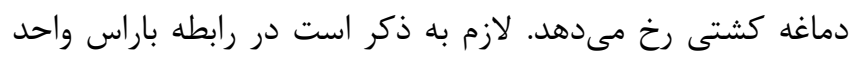

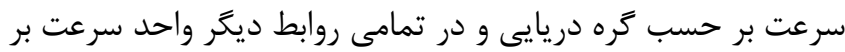
حسب متر بر ثانيه مىباشد.
به مشخصات ابعادى شناور و كانال و نيز سرعت عبور شناور تعيين مىشود.

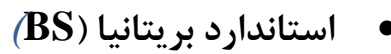

مؤسسه استاندارد بريتانيا^^، مرجع استانداردكذارى در كشور انغَلستان است.

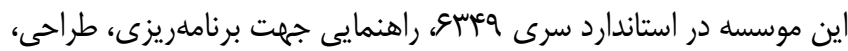
ساخت و نكمهدارى سازههاى دريايى ارائه مىدهد.

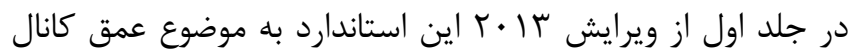
اشاره شده و با مبنا قراردادن توصيدهاى بيانك، عوامل موثر در تعيين عمق كانال را معرفى كرده است. در اين بخش ضمن تعريف اسكوات، بر لزوم توجه و تعيين آن تاكيد شده است و به اين اين نكته

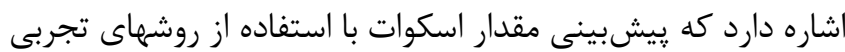
در طراحى كانال با عدم قطعيت همراه است. اين عدم قطعيت بايد

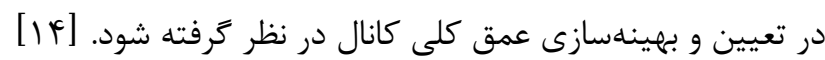

\section{آيين نامه كشور كانادا}

كتابجه راهنماى طراحى كانال، توسط كَروه توسعه آبراههاى كارد

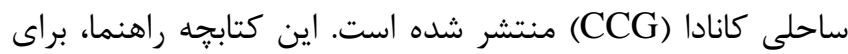

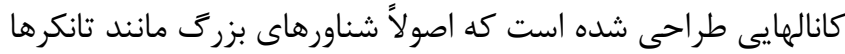

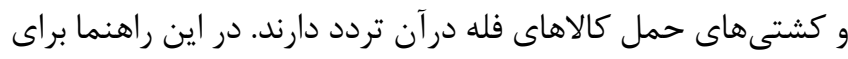
محاسبه بارامتر اسكوات از فرمول اريزلو استفاده شده است إن.

\section{ب- ب- روششناسى تحقيق}

در اين يزوهش گردآورى اطلاعات بريشينه و مبانى نظرى تحقيق، به روش كتابخانهاى و از كتب، تزارشات و مقالات فارسى و لاتين جمع -

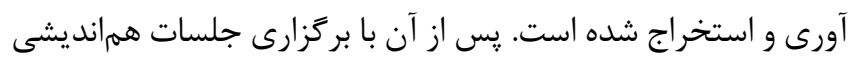

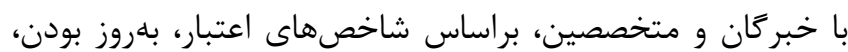

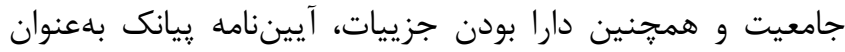

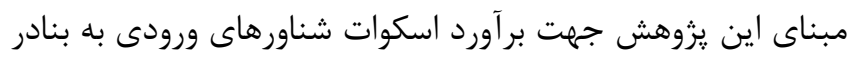

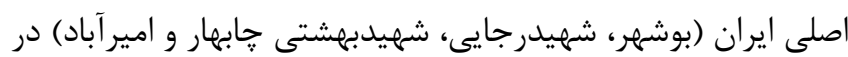

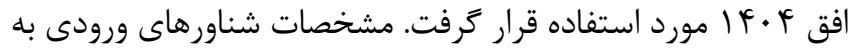

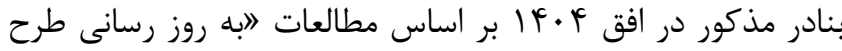
جامع بنادر بازركانى" كه در سال هوس ا انجام شده، استخراج شده 


\begin{tabular}{|c|c|c|c|c|}
\hline ضرايب & روابط & & & عنوان \\
\hline 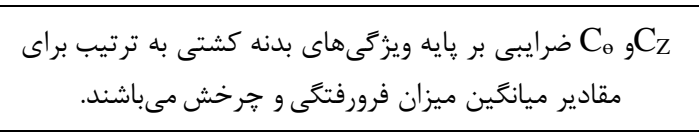 & $\mathrm{S}_{b_{T}}=\left(C_{z}+C_{\theta}\right) \frac{\nabla}{L_{p p}^{2}} \frac{F_{n h}^{2}}{\sqrt{1-F_{n h}^{2}}}$ & & (1) & تاك \\
\hline 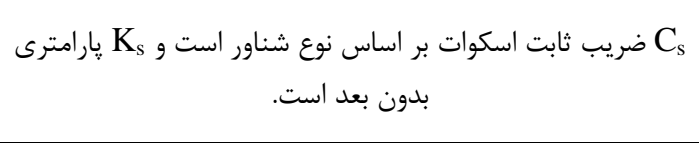 & $S_{b H}=C_{s} \frac{\nabla}{L_{p p}^{2}} \frac{F_{n h}^{2}}{\sqrt{1-F_{n h}^{2}}} K_{s}$ & & $(r)$ & هوسكا/ \\
\hline ضريب ثابت اسكوات بر اساس نوع شناور است. & $S_{b, I}=C_{s} \frac{\nabla}{L_{p p}^{2}} \frac{F_{n h}^{2}}{\sqrt{1-F_{n h}^{2}}}$ & & (ז) & آيكورلز \\
\hline 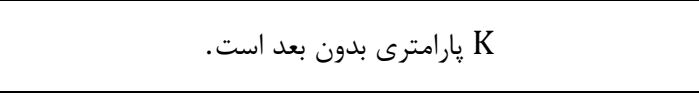 & $\mathrm{S}_{\mathrm{Max}, \mathrm{B} 3}=\frac{\mathrm{C}_{\mathrm{B}} \mathrm{V}_{\mathrm{k}}^{2}}{100 / \mathrm{K}}$ & & $\left(F^{\mathbb{F}}\right)$ & باراس \\
\hline يارامتر بدون بعد K يك ضريب تصحيح است. & $S_{b, E 2}=0.298 \frac{h^{2}}{T}\left(\frac{V_{s}}{\sqrt{g T}}\right)^{2.289}\left(\frac{h}{T}\right)^{-2.972}\left(K_{b}\right)$ & & (D) & اريزلو \\
\hline 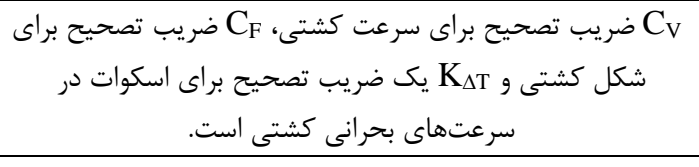 & $\begin{array}{l}\mathrm{Sb}, \mathrm{R}=\mathrm{C}_{\mathrm{v}} \mathrm{C}_{\mathrm{f}} \mathrm{K}_{\Delta \mathrm{T}} \mathrm{T} \\
\mathrm{Ss}, \mathrm{R}=\mathrm{C}_{\mathrm{v}} \mathrm{K}_{\Delta \mathrm{T}} \mathrm{T}\end{array}$ & & (9) & روميش \\
\hline & $S_{b, Y}=\left[\left(0.7+1.5 \frac{1}{\frac{h}{T}}\right)\left(\frac{C_{B}}{\frac{L_{p p}}{B}}\right)+15 \frac{1}{\frac{h}{T}}\left(\frac{C_{B}}{\frac{L_{p p}}{B}}\right)\right.$ & $\frac{V_{e}^{2}}{g}$ & $(\vee)$ & يوشيمورا \\
\hline
\end{tabular}

آزمايشگاهى مىباشند، لذا در برخى روابط مقادير يارامترها بسيار

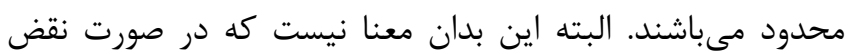

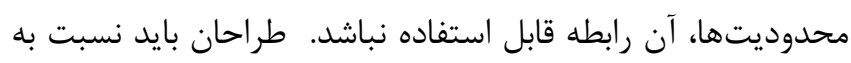
سرعت مورد استفاده در طراحى خود توجه خاص داشته باشند؛ زيرا اين روابط براى محدوده خاصى از سرعتها توسعه داده شدهاند.

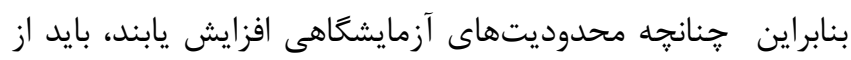
قضاوتهاى مهندسى استفاده كرد.

جدول r- محدوديتهاى يارامترهاى محاسباتى اسكوات در روابط تجربى مختلف

\begin{tabular}{|c|c|c|c|c|c|c|c|c|}
\hline يوشيمورا & روميش & اريزلو & باراس & آيكورلز & هوسكا/Fاليو & تاى & ابطه & \\
\hline$\cdot / \Lambda-\cdot / \Delta \Delta$ & - & $\geq \cdot 11$ & $\cdot / \Lambda \Delta-\cdot / \Delta$ & $\cdot 11-\cdot 19$ & $\cdot 11-\cdot / 9$ & - & $\mathrm{C}_{\mathrm{B}}$ & \\
\hline- & - & - & $\cdot / r \Delta-\cdot / 1$ & - & - & - & S & \\
\hline$\Delta / \Delta-\Gamma / \Delta$ & $r / 9$ & $r / q-r / F$ & - & $r / \Delta-r / 1 q$ & $r / \Delta-r / 1 q$ & - & $\mathrm{B} / \mathrm{T}$ & $\beta$ \\
\hline$\geq 1 / \pi$ & $r / r \Delta-1 / 19$ & $r / \Delta-1 / 1$ & $1 / 4-1 / 1$ & $r / \cdot-1 / 1$ & $r / \cdot-1 / 1$ & - & $\mathrm{h} / \mathrm{T}$ & \\
\hline- & - & - & - & $\cdot|\Lambda|-\cdot / r T$ & $\cdot|\Lambda|-\cdot / T T$ & - & $\mathrm{h}_{\mathrm{T}} / \mathrm{h}$ & \\
\hline$\varepsilon / \cdot-r / V$ & $\Lambda / V$ & $9 / \Lambda-9 / V$ & - & $\Lambda / \Delta-\Delta / \Delta$ & $\Lambda / \Delta-\Delta / \Delta$ & - & $\mathrm{L} / \mathrm{B}$ & \\
\hline- & $r T / q$ & - & - & $r \cdot / r-\mid 9 / 1$ & $r \cdot / r-19 / 1$ & - & $\mathrm{L} / \mathrm{T}$ & \\
\hline
\end{tabular}

جهت بررسى بيشتر روابط، در جدول ץ يارامترهاى موثر در محاسبه اسكوات شناورها به تفكيك هر رابطه نشان داده شده است.
همانطور كه در جدول ا نشان داده شده است، تمامى روابط، داراى ضريب مخصوص آن رابطه مى باشند. هر كدام از اين ضرايب تابعى از

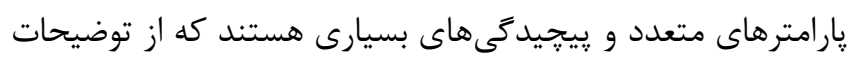

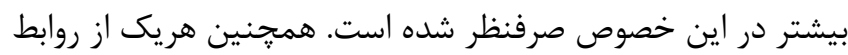
ذكر شده داراى محدوديتهايى در مقادير :ارامترهاى خود، ناشى از

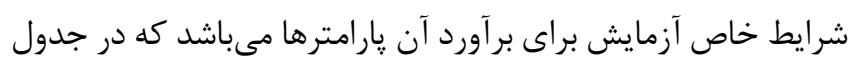

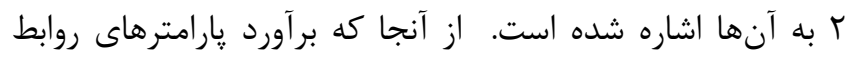

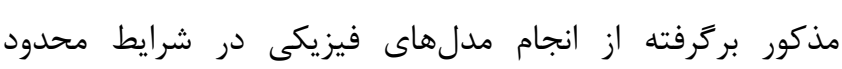
لازم به ذكر است، رابطه آيكورلز براى آبراهههاى نامحدود توسعه داده

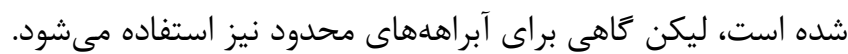


جدول r- عوامل موثر در محاسبه اسكوات شناورها به تفكيك روابط تجربى

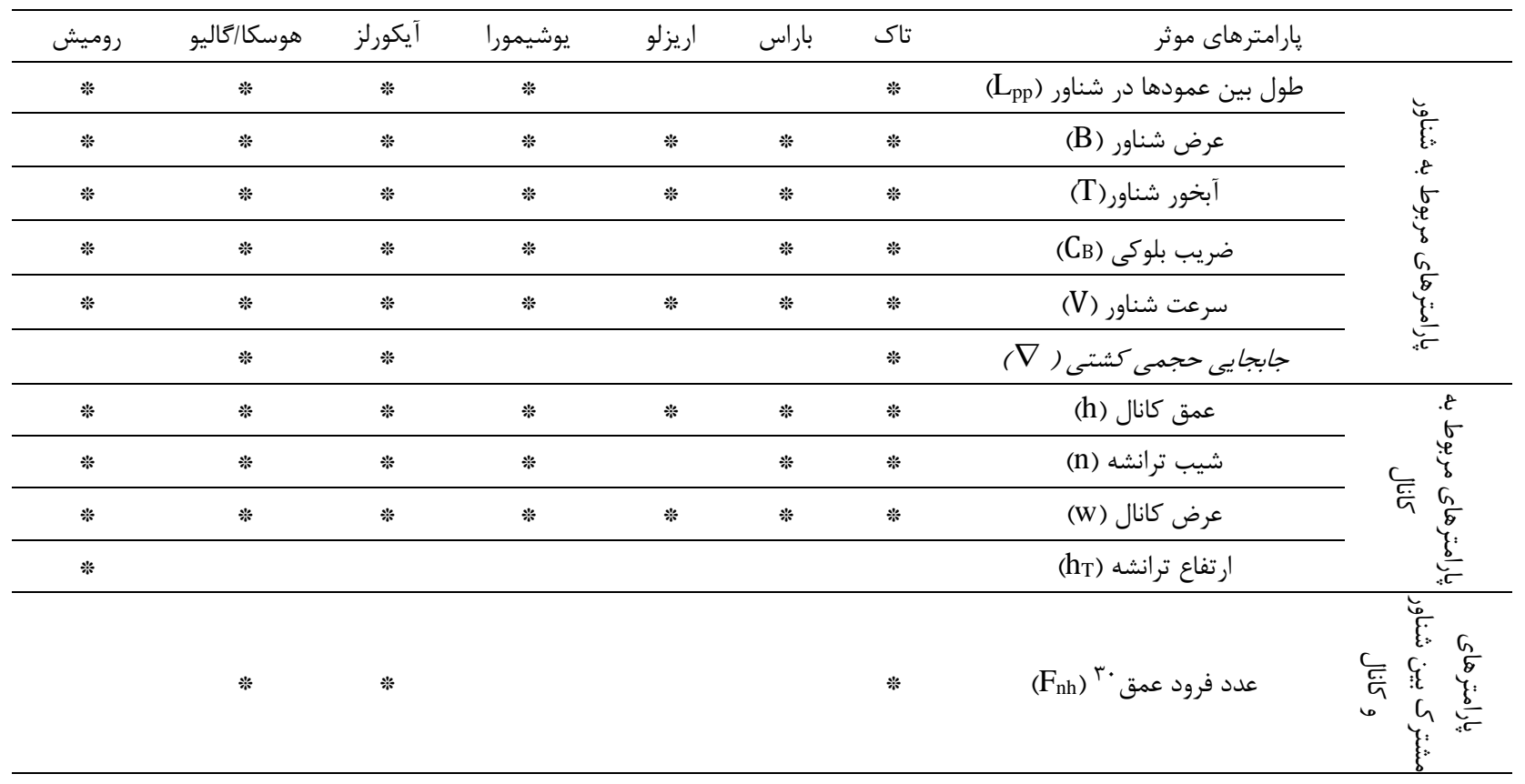

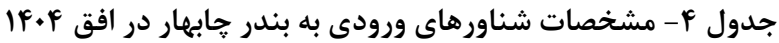

\begin{tabular}{|c|c|c|c|c|c|}
\hline ضلوكى & $\begin{array}{l}\text { شناور } \\
\text { (m) }\end{array}$ & $\begin{array}{l}\text { شناور } \\
\text { (m) }\end{array}$ & 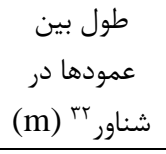 & مرده بار & شناور \\
\hline$\cdot 199$ & $\mid f / D$ & $r \cdot / r$ & TAF & $\wedge \cdots$ & كانتينرى \\
\hline - IAT & If & $r \varepsilon / \Delta$ & TrA & $\wedge \cdots$ & فلهبر \\
\hline$\cdot / 1$ & If & $r$. & TTH & $\wedge \cdots$ & تانكر \\
\hline
\end{tabular}

همجنين اطلاعات مربوط به مشخصات كانال بندرشهيد بهشتى، جهت محاسبه اسكوات شناورهاى ورودى به بندر، بر اساس نقشه -

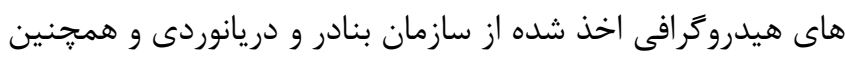
تخمينهاى كارشناسى، به شرح ذيل مى باشد: نوع كانال: محدود طول كانال دسترسى: • . .

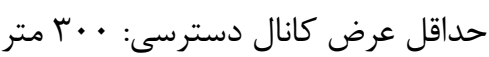
حداقل عمق كانال دسترسى: 19 متر شيب كانال (n) ارتفاع ترانشه (h) با توجه به اطلاعات و مفروضات ذكر شده، اسكوات شناورهاى ورودى به بندر، براساس روابط تجربى مورد استناد در آييننامه ييانك

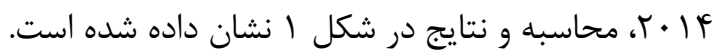

بر اساس جدول r و جدول r ملاحظه مىشود كه رابطه تاك داراى كمترين محدوديت و روابط هوسكا/گاليو و آيكورلز داراى بيشترين

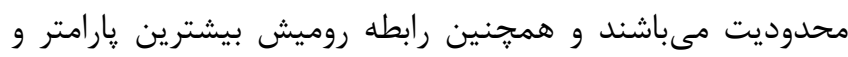

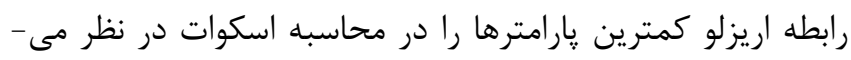
كيرند. در ادامه با استفاده از روشهاى تجربى مذكورئ مقادئ مقادير اسكوات

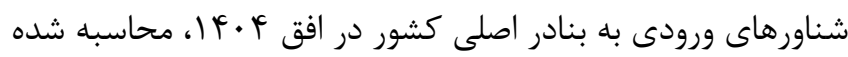

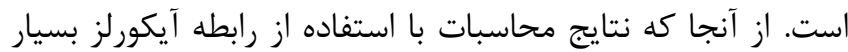
نزديك به نتايج هوسكا مىباشد، لذا نمودار آيكورلز در محاسبات نشان داده نشده است.

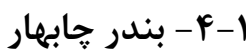
بندر جابهار واقع در استان سيستان و بلوجستان و شمال درياى عمان، شامل دو بندر مهرم شهيدكلانترى و شهيد بهشتى است. در در

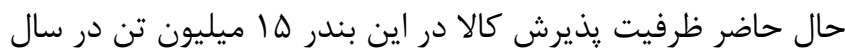

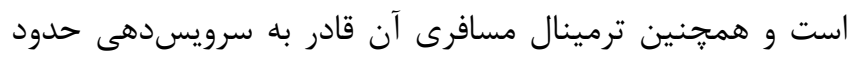

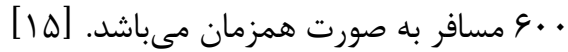
بر اساس :يشبينىهاى ارائه شده در مطالعات لابه روز رسانى طرح

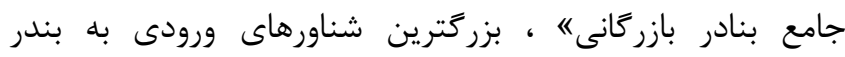

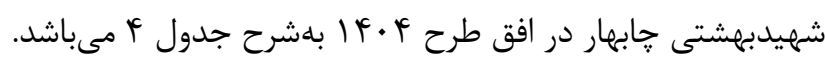


جدول ه- مشخصات شناورهاى ورودى به بندر بوشهر در افق طرح FfF

\begin{tabular}{|c|c|c|c|c|c|}
\hline ضلوكى & $\begin{array}{l}\text { آبخور } \\
\text { (m) }\end{array}$ & $\begin{array}{l}\text { شرض } \\
\text { (m) } \\
\end{array}$ & طمول بين & $\begin{array}{c}\text { وزن بار } \\
\text { (t) } \\
\text { (t) }\end{array}$ & شناور \\
\hline .199 & $1 \pi / \pi$ & rT & TVD & $9 \ldots$ & كانتينرى \\
\hline$\cdot / 1$ & $I T / \Lambda$ & Tr/D & rI. & $9 \ldots$ & فلهبر \\
\hline . / 99 & r & צ & $r \cdot \varphi$ & $4 \ldots$ & تانكر \\
\hline
\end{tabular}

همجنين اطلاعات مربوط به مشخصات كانال بندر بوشهر، جهت محاسبه اسكوات شناورهاى ورودى به بندر، بر اساس نقشه ماسه هيدروگرافى اخذ شده از سازمان بنادر و دريانوردى و همجنين تخمينهاى كارشناسى به شرح ذيل مىباشد: نوع كانال: محدود طول كانال دسترسى: • • . حداقل عرض كانال دسترسى: • •l| متر

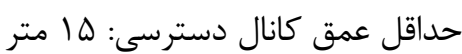
شيب كانال (n) ارتفاع ترانشه (h) با توجه به اطلاعات و مفروضات ذكر شده، اسكوات شناورهاى ورودى به بندر، براساس روابط تجربى مورد استناد در آييننامه ييانك

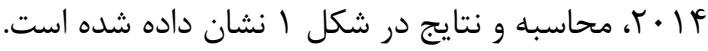
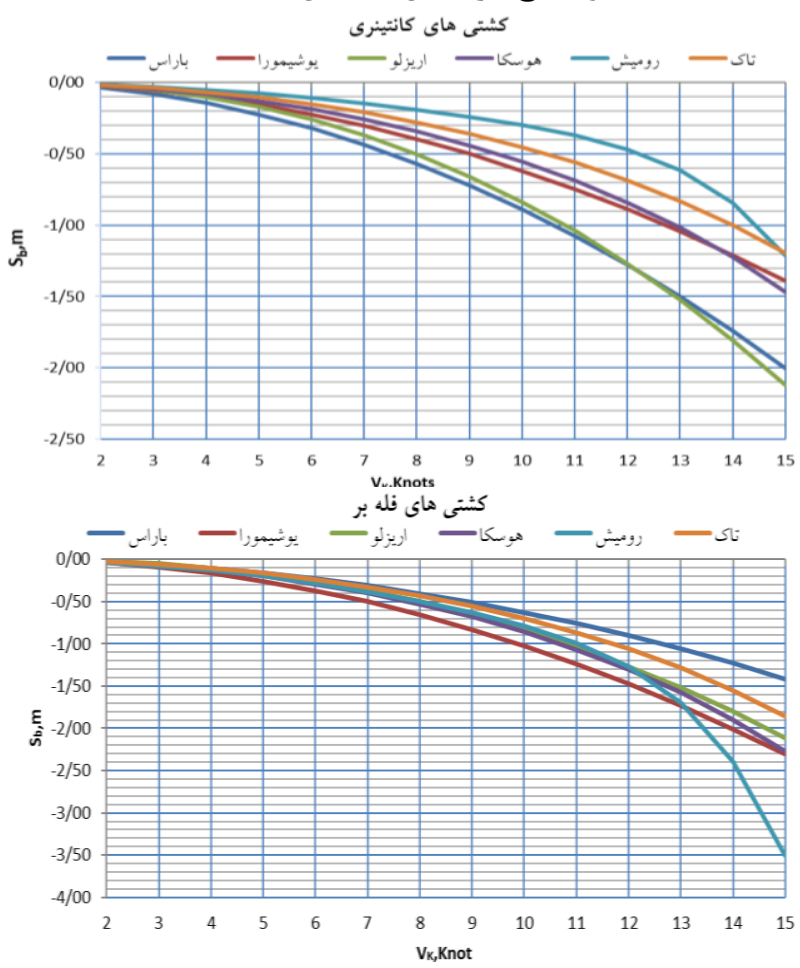
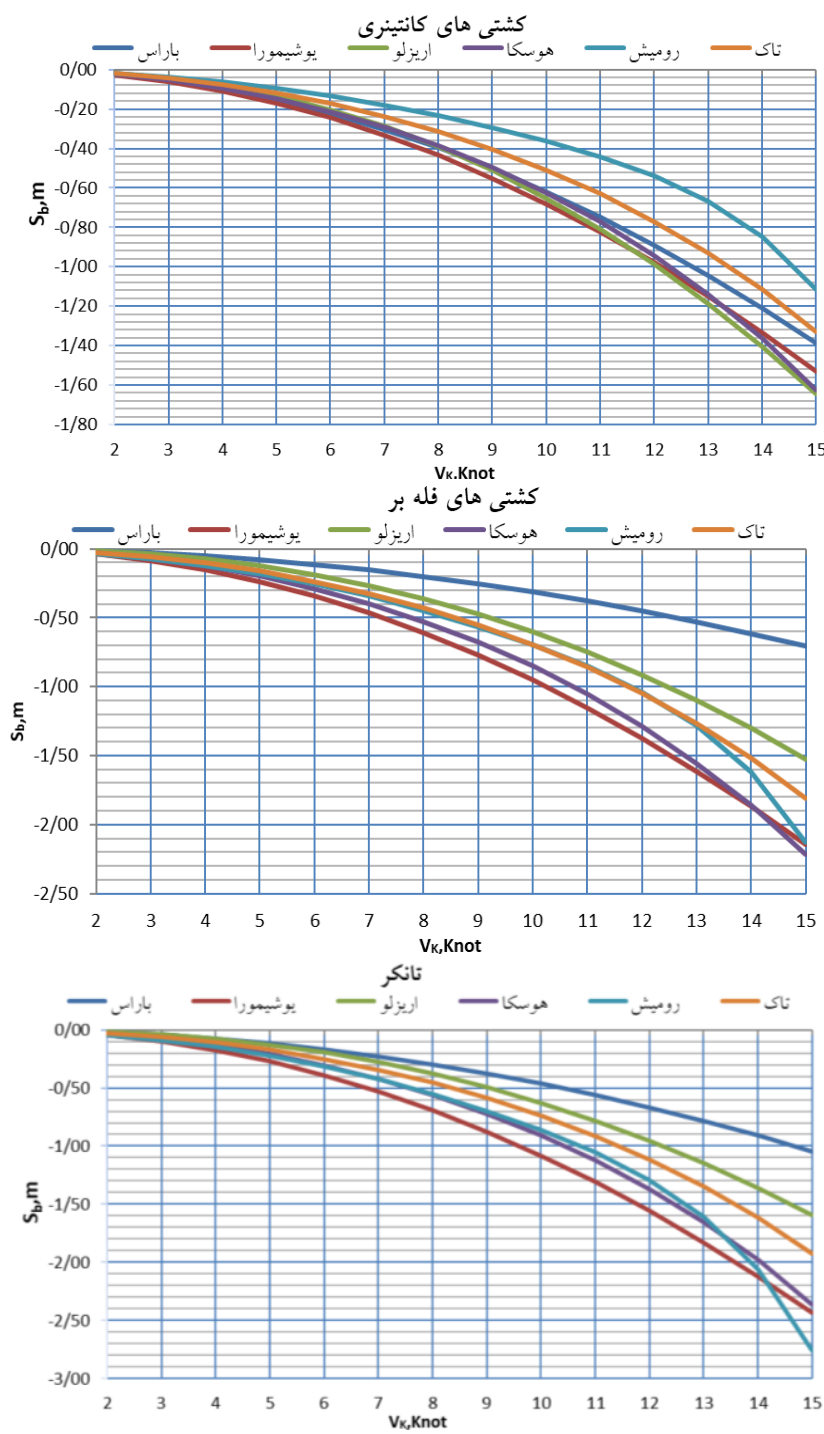

شكل ا- محاسبه اسكوات دماغه به تفكيك شناورهاى ورودى به بندر

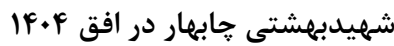

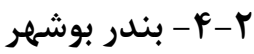
در اين بندر، خدماتى مانند حمل و نقل كالاهاى فله، كانتينر، عمومى، مواد نفتى، نكَهدارى و يردازش كالا، محصولات سردخانهاى

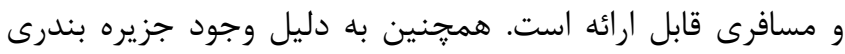
نخين با مساحت بالغ بر • 19 هكتار و طرحهاى توسعه آن، مى هوتوان

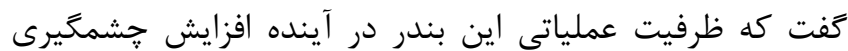
خواهد يافت. بر اساس ريشبينىهاى ارائه شده در مطالعات لابه روز رسانى طرح

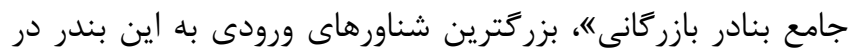

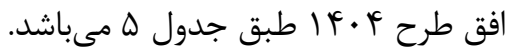



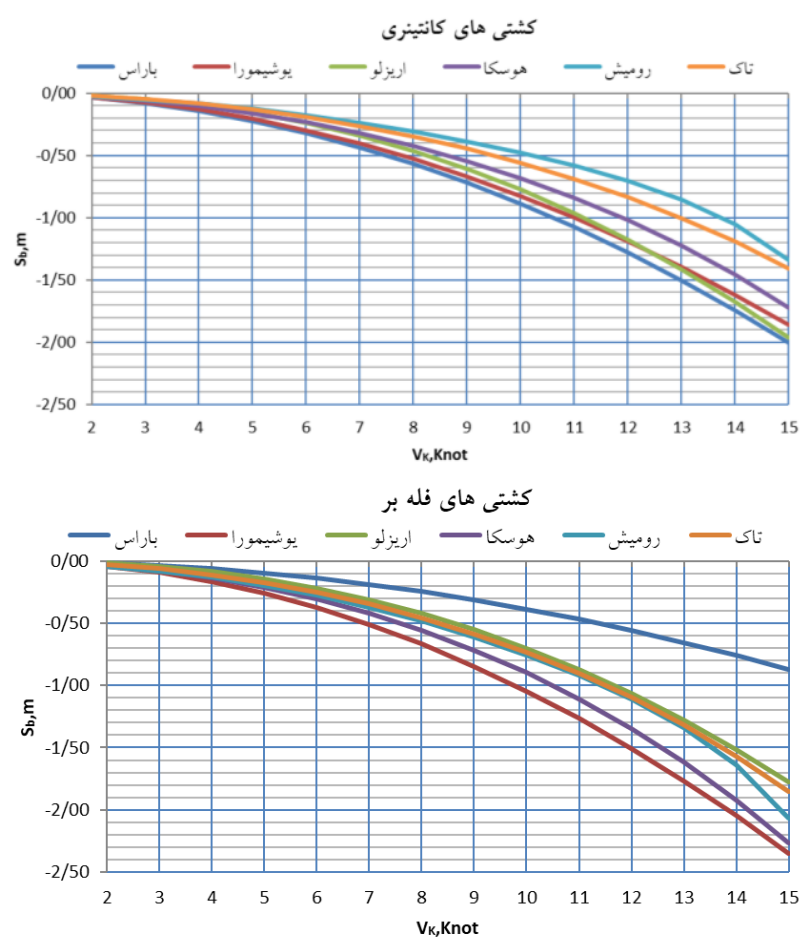

تانكر

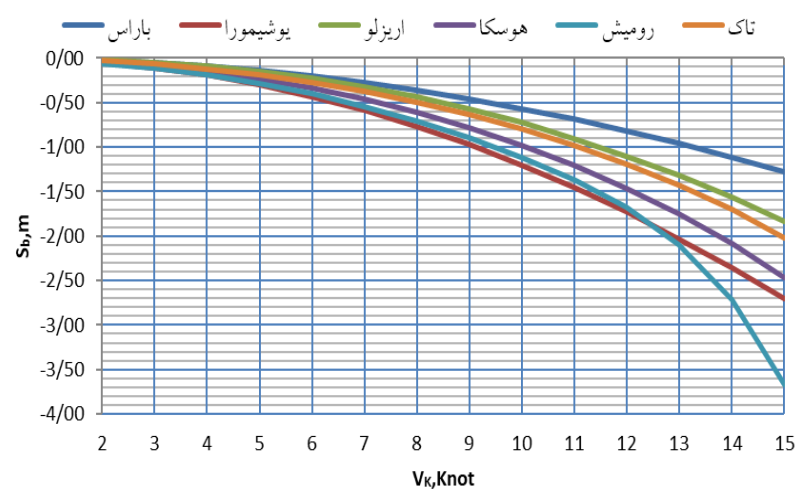

شكل r- محاسبه اسكوات دماغه به تفكيك شناورهاى ورودى به بندر شهيدرجايى در افق If.F

\section{ب-f}

منطقه ويزه اقتصادى بندر امير آباد در شرق استان مازندران و فاصله اله كيلومترى شهرستان سارى قرار دارد. اين بندر مى تواند در زمينه حمل و نقل غلات، كالاى عمومى، فرآوردههاى نفتى، اسكلههاى رورو، كانتينرى، نگگهدارى و : يردازش كالا براى صاحبان كالا و و

$$
\text { بخشهاى دولتى به ارائه خدمت بيردازد. }
$$

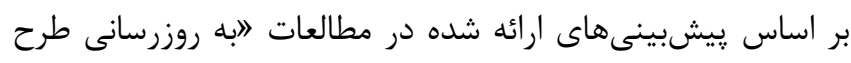

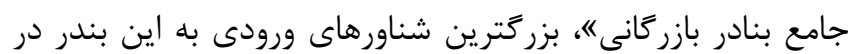

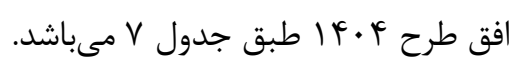

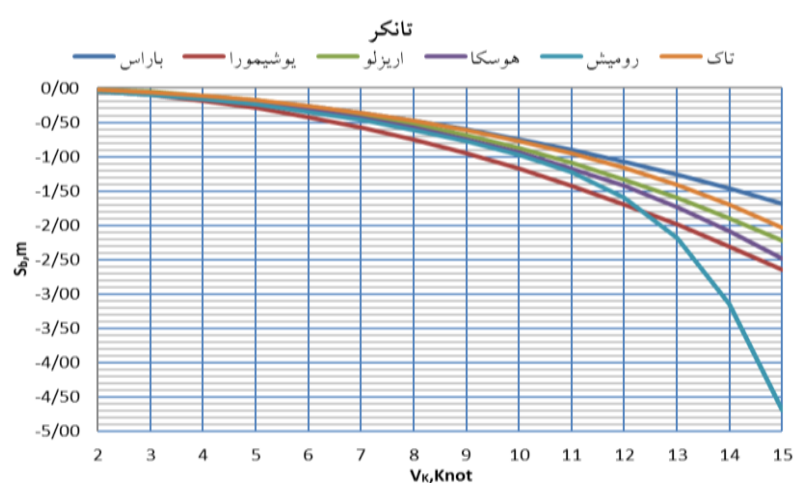

شكل r - محاسبه اسكوات دماغه به تفكيك شناور هاى ورودى به بندر

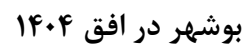

r-F - r- بندر شهيد رجايى

منطقه ويزه اقتصادى بندر شهيد رجايى در شمال جزيره قشم و تنگَه هرمز در فاصله ها كيلومترى خروجى غربى شهر بندر عباس واقع

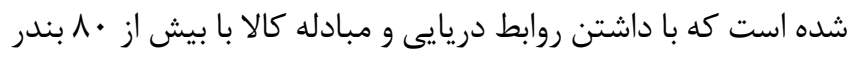
معروف بين المللى، بيش از يك سوم تجارت دريايى ايران را يشتيبانى

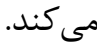
بر اساس ريشبينىهاى ارائه شده در مطالعات ابه روز رسانى طرح

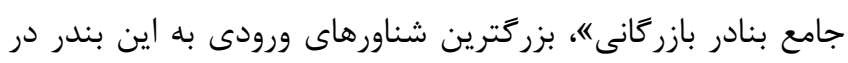

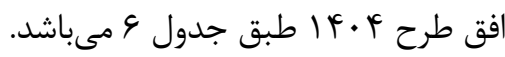

\begin{tabular}{|c|c|c|c|c|c|}
\hline بلوكى & $\begin{array}{l}\text { شناور } \\
\text { (m) }\end{array}$ & $\begin{array}{l}\text { شرض } \\
\text { (m) } \\
\end{array}$ & 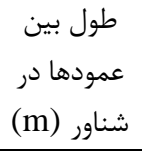 & $\begin{array}{c}\text { وزن بار } \\
\text { (t) } \\
\end{array}$ & شناور \\
\hline$\cdot \mid 9 \Lambda$ & $19 / 0$ & $\Delta 9$ & rیD & $r \ldots .$. & كانتينر \\
\hline - IAT & $I V / D$ & FF & TVE & $10 \ldots$ & فلهبر \\
\hline$\cdot \mid \Lambda$ & $19 / 9$ & $49 / 0$ & $r V$. & $10 \ldots$ & تانكر \\
\hline
\end{tabular}

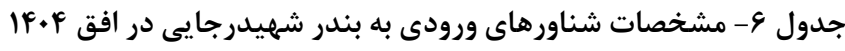

همجنين اطلاعات مربوط به مشخصات كانال بندرشهيدرجايى، جهرت محاسبه اسكوات شناورهاى ورودى به بندر، بر اساس نقشه

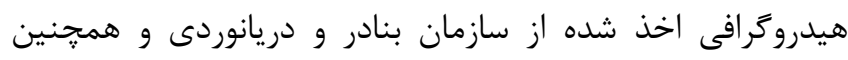
تخمينهاى كارشناسى، به شرح ذيل مى باشد: نوع كانال: محدود

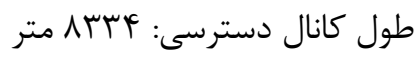

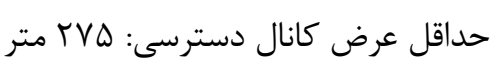
حداقل عمق كانال دسترسى: 19 متر شيب كانال (n): ارتفاع ترانشه (h) با توجه به اطلاعات و مفروضات ذكر شده، اسكوات شناورهاى ورودى به بندر، براساس روابط تجربى مورد استناد در آييننامه پيانكى

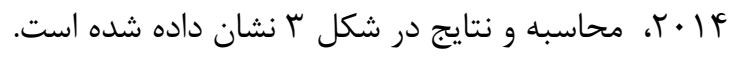




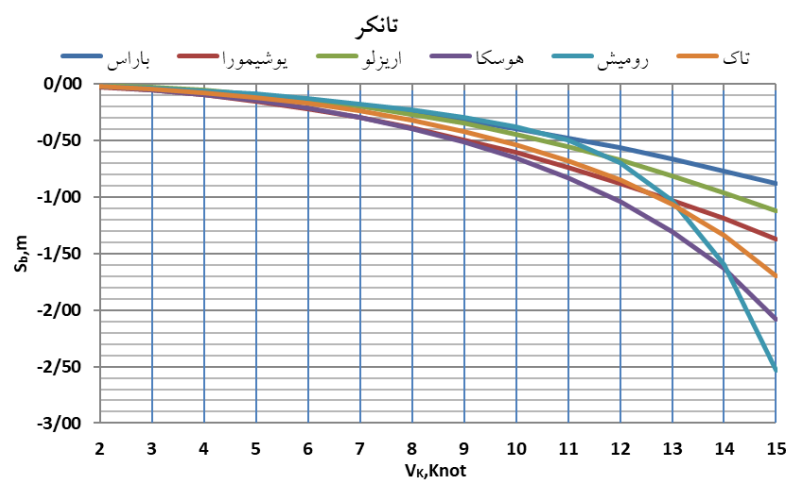

شكل F- محاسبه اسكوات دماغه به تفكيك شناورهاى ورودى به بندر امير آباد در افق IF.F

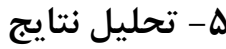

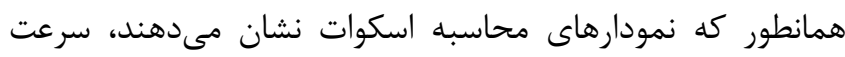

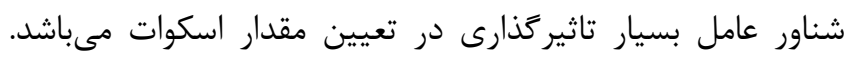

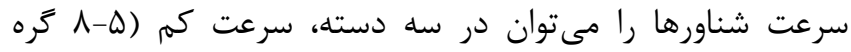

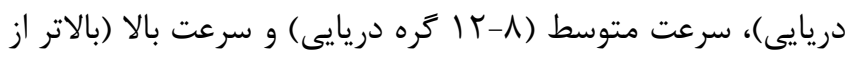

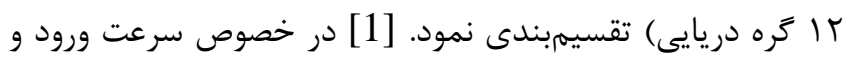
تردد شناورها در كانال بنادر، با كارشناسان و خبر كان در امور ناوبرىى، مصاحبه هايى انجام شد. بر اساس نظرات متخصصين مذكور، در حال

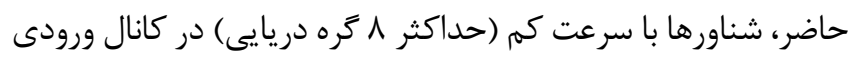

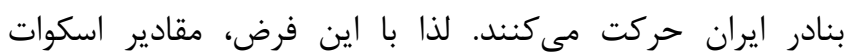
محاسباتى براى سرعت ^ گره دريايى در انواع شناورهاى طرح بنادر مورد مطالعه، در جدول 1 ارائه شده است.
جدول V - مشخصات شناورهاى ورودى به بندر امير آباد در افق IfF

\begin{tabular}{|c|c|c|c|c|c|}
\hline ضلوكى & $\begin{array}{l}\text { شنخور } \\
\text { (m) }\end{array}$ & $\begin{array}{l}\text { شناور } \\
\text { (m) }\end{array}$ & 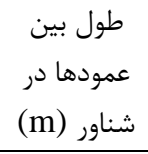 & وزن بار & شناور \\
\hline$\cdot / V G$ & $V / \Delta$ & 11 & $I K F$ & $1 \ldots$ & فلهبر \\
\hline$\cdot / V T$ & $\mathrm{~V} / \mathrm{\Lambda}$ & 19 & Irv & $1 \ldots$ & تانكر \\
\hline
\end{tabular}

همجنين اطلاعات مربوط به مشخصات كانال بندراميرآباد، جهت

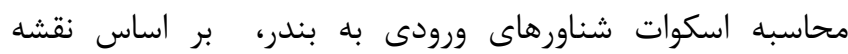
هيدروكرافى اخذ شده از سازمان بنادر و دريانوردى و همجنين تخمينهاى كارشناسى، به شرح ذيل مى اخداشد: نوع كانال: محدود طول كانال دسترسى: • . . حداقل عرض كانال دسترسى: • r Tr متر حداقل عمق كانال دسترسى: • • متر شيب كانال (n): ارتفاع ترانشه (h) با توجه به اطلاعات و مفروضات ذكر شده، اسكوات شناورهاى ورودى تُشى به بندر، براساس روابط تجربى مورد استناد در آيينامه بيانك

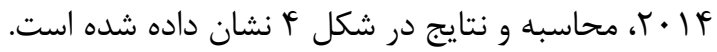

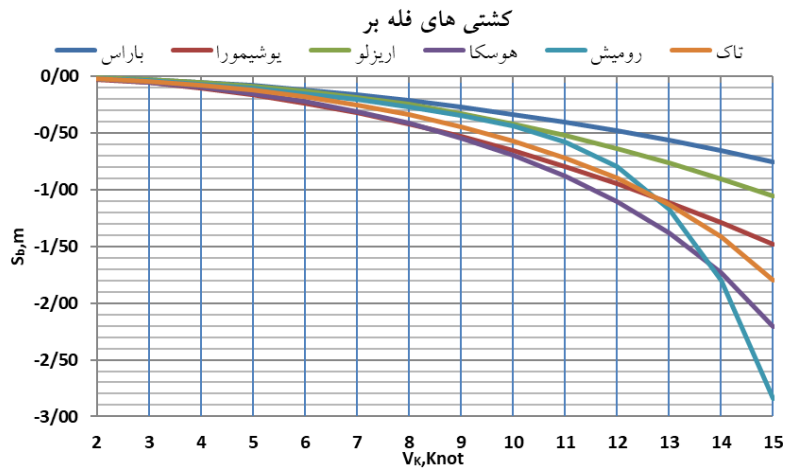


جدول ^- اسكوات محاسباتى براى شناورهاى طرح برخى بنادر مههم كشور در افق ؟+F( (سرعت ^ كره دريايى)

\begin{tabular}{|c|c|c|c|c|c|c|c|c|c|c|c|c|}
\hline \multicolumn{4}{|c|}{ شناور تانكرى } & \multicolumn{4}{|c|}{ شناور فله بر } & \multicolumn{4}{|c|}{ شناور كانتينرى } & \multirow[b]{2}{*}{ برر بندى مورد } \\
\hline 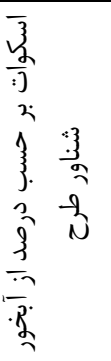 & $\begin{array}{l}\frac{8}{3} \\
\frac{3}{3} \\
\frac{2}{3} \\
\vdots 3 \\
3 \\
3\end{array}$ & $\begin{array}{l}\overline{3} \\
-3 \\
3 \\
3 \\
3 \\
3 \\
\frac{3}{3} \\
\frac{3}{3} \\
\frac{3}{3}\end{array}$ & 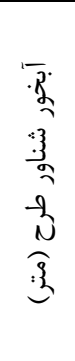 & 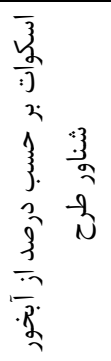 & $\begin{array}{l}\frac{8}{3} \\
\overline{3} \\
\frac{3}{3} \\
\widehat{3} \\
3 \\
3\end{array}$ & $\begin{array}{l}\overline{3} \\
\overline{3} \\
\frac{3}{3} \\
\frac{3}{3} \\
\frac{3}{3} \\
\frac{3}{3} \\
3\end{array}$ & 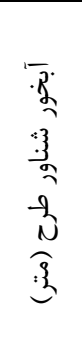 & 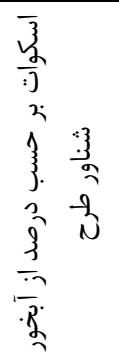 & $\begin{array}{l}\frac{8}{3} \\
\frac{1}{3} \\
\frac{3}{3} \\
\frac{3}{3} \\
3\end{array}$ & $\begin{array}{l}\overline{3} \\
\overline{3} \\
\frac{3}{3} \\
\frac{3}{3} \\
\frac{3}{3} \\
\frac{3}{3} \\
\frac{3}{3}\end{array}$ & $\begin{array}{l}1 \\
2 \\
3 \\
3 \\
3 \\
-3 \\
-3 \\
\hat{N} \\
3 \\
3\end{array}$ & \\
\hline$r / 9$ & $\cdot / 4 V$ & تاك & \multirow{6}{*}{ ir } & $r / 1$ &.$/ 4$ & باراس & \multirow{6}{*}{$I r / \Lambda$} & $1 / x^{c}$ &.$/ 19$ & روميش & \multirow{6}{*}{ Ir.r } & \multirow{6}{*}{ بوشهر } \\
\hline$r / V$ & $\cdot / 4 \Lambda$ & باراس & & $r / 4$ & r & تاك & & $r / 1$ & $\cdot / T \wedge$ & تاك & & \\
\hline$\varphi / 1$ &.$/ \Delta r$ & اريزلو & & $r / 9$ &.$/ 6$ & روميش & & T/9 & $\cdot / \mu F$ & هوسكا & & \\
\hline$f / \Delta$ & $\cdot / \Delta \Lambda$ & هوسكا & & $r / 9$ & $\cdot / \Delta$ & اريزلو & & r & $\cdot / 4$ & يوشيمورا & & \\
\hline$F / V$ & $\cdot|9|$ & روميش & & $F / 1$ & $\cdot \mid \Delta r$ & هوسكا & & $\Gamma / \Lambda$ & $\cdot / 0$ & اريزلو & & \\
\hline$\Delta / \Lambda$ & $\cdot / V \Delta$ & يوشيمورا & & $\Delta / r$ & .199 & يوشيمورا & & $r / r$ & $\cdot / \Delta V$ & باراس & & \\
\hline$r / 1$ &. & باراس & \multirow{6}{*}{$19 / 9$} & $1 / 4$ & $\cdot \pi \Delta$ & باراس & \multirow{6}{*}{$\mid V / \Delta$} & $1 / 9$ & . & روميش & \multirow{6}{*}{19.0} & \multirow{6}{*}{ شهيدرجايى } \\
\hline$r / \Delta$ & r & اريزلو & & $r / F$ &.$/ 4 T$ & اريزلو & & $r / 1$ & . & تاك & & \\
\hline$r$ & 10 & تاك & & $r / 9$ & .148 & تاك & & $r / \omega$ & . MT & هوسكا & & \\
\hline$r / \varphi$ &.$|9|$ & هوسكا & & $r / V$ &.$/ 4 A$ & روميش & & $r / \Lambda$ & .148 & اريزلو & & \\
\hline$r / r$ & $\cdot / V I$ & روميش & & $r / r$ & $\cdot 1 \Delta 9$ & هوسكا & & $r / r$ & . $/ \Delta r$ & يوشيمورا & & \\
\hline$r / 9$ & $\cdot / V V$ & يوشيمورا & & $r / \Lambda$ & $.19 \mathrm{~V}$ & يوشيمورا & & $r / \Delta$ &.$/ \Delta V$ & باراس & & \\
\hline$r / l$ & $\cdot / r$ & باراس & \multirow{6}{*}{14} & $1 / 4$ & $\cdot / r$ & باراس & & $1 / 9$ & Tr/. & روميش & \multirow{6}{*}{19.0} & \multirow{6}{*}{ شهيدبهشتى } \\
\hline$r / V$ & . & اريزلو & & $r / 9$ & . & اريزلو & & $r / T$ & . & تاك & & \\
\hline$r / r$ & .148 & تاك & & $r / 1$ & . & تاك & $I^{k}$ & $T / V$ & . & هوسكا & & \\
\hline$r / 9$ & $\cdot / \Delta \Delta$ & روميش & & $r / r$ & $\cdot / 4 \Delta$ & روميش & & $r / V$ & $\cdot / 49$ & اريزلو & & \\
\hline$r$ & $\cdot 109$ & هوسكا & & $\Gamma / \Lambda$ & $\cdot \mid \Delta r$ & هوسكا & & $r / \Lambda$ &.$/ 4$ & باراس & & \\
\hline$F / q$ & .199 & يوشيمورا & & $k / F$ & .191 & يوشيمورا & & r & $\cdot \mid k F$ & يوشيمورا & & \\
\hline$r / 9$ & r & روميش & \multirow{6}{*}{$V / \Lambda$} & $r / \Lambda$ & $\cdot|r|$ & باراس & \multirow{6}{*}{$V / \Delta$} & - & - & - & & \multirow{6}{*}{ اميرآباد } \\
\hline$r / r$ & $\cdot / T \Delta$ & باراس & & $r / r$ & $\cdot \pi \Delta$ & اريزلو & & - & - & - & & \\
\hline$r / \Delta$ & $\cdot / T V$ & اريزلو & & $r / 9$ & $\cdot / r V$ & روميش & & - & - & - & & \\
\hline$f / 1$ & TrT & تاك & & $F / \Delta$ &.$/ M F$ & تاك & & - & - & - & & \\
\hline$\Delta$ & . & هوسكا & & $\Delta / 9$ & . MT & هوسكا & & - & - & - & & \\
\hline$\Delta$ &.$/ 49$ & يوشيمورا & & $\Delta / 9$ & . KT & يوشيمورا & & - & - & - & & \\
\hline
\end{tabular}


در كشتىهاى فلهبر، بر خلاف كشتىهاى كانتينرى، رابطه باراس در

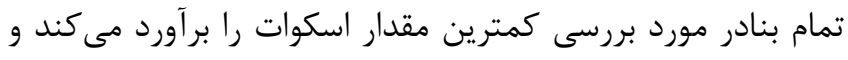

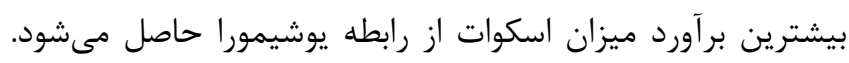

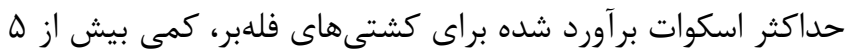

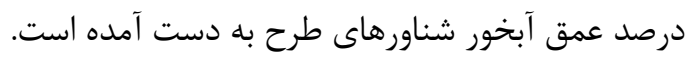

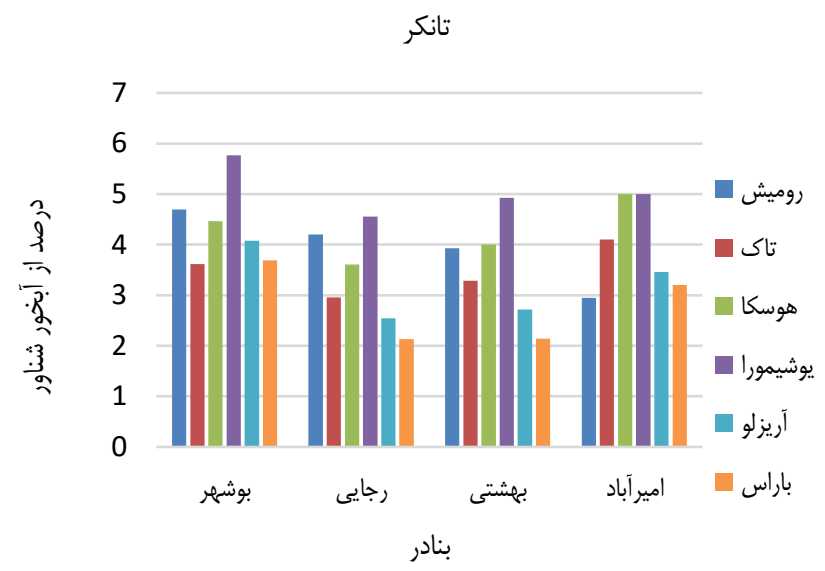

شكل V- مقادير اسكوات بر حسب درصد از آبخور تانكرها در سرعت 1 ـ كره دريايى به تفكيك بنادر

در مورد تانكرها نيز، نتايج به دست آمده تقريبا مشابه كشتىهاى

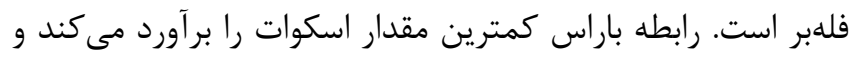
بيشترين برآورد مربوط به رابطه يوشيمورا است. حداكثر اسكوات

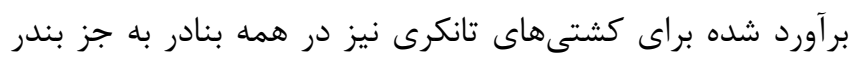

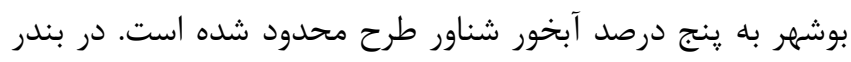
بوشهر اين مقدار به حدود ^.0 درصد رسيده است.
ا-ه- مقايسه نتايج بين بنادر مختلف به تفكيك نوع شناور

$$
\text { كشتى هاى كانتينرى }
$$

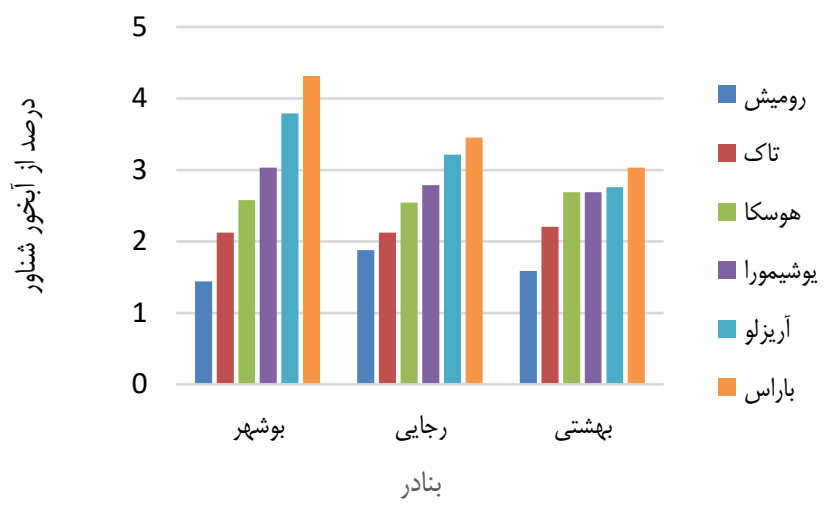

شكل ه- مقادير اسكوات بر حسب درصد از آبخور كشتىهاى كانتينرى در سرعت ^ گ عره دريايى به تفكيك بنادر

براى كشتى هاى كانتينرى، در همه بنادر مورد بررسى، رابطه روميش كمترين مقدار و رابطه باراس بيشترين مقدار اسكوات را تخمين

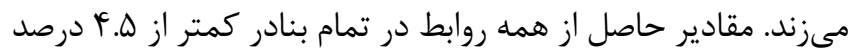

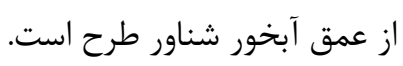

كشتى هاى فله بر

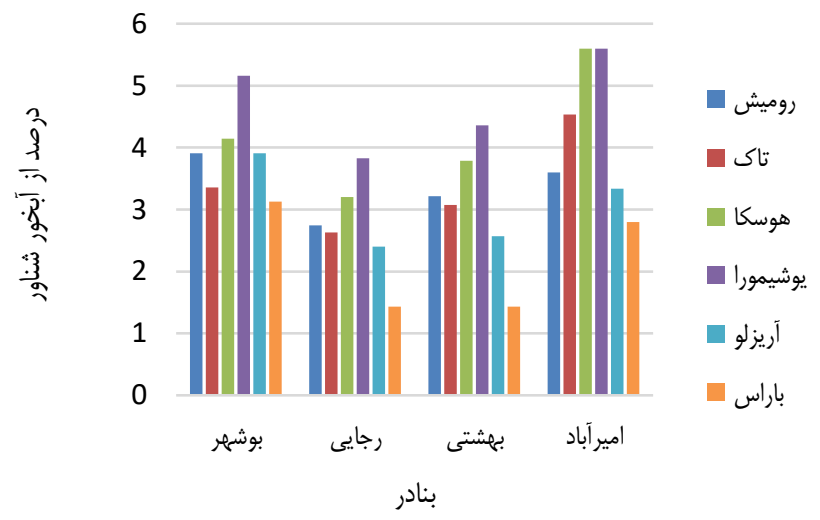

شكل \&- مقادير اسكوات بر حسب درصد از آبخور كشتىهاى فلهبر در سرعت ^ گ گره دريايى به تفكيك بنادر 
r-ه - مقايسه نتايج بر اساس نوع شناورها به تفكيك بنادر

بندر شهيد رجايى
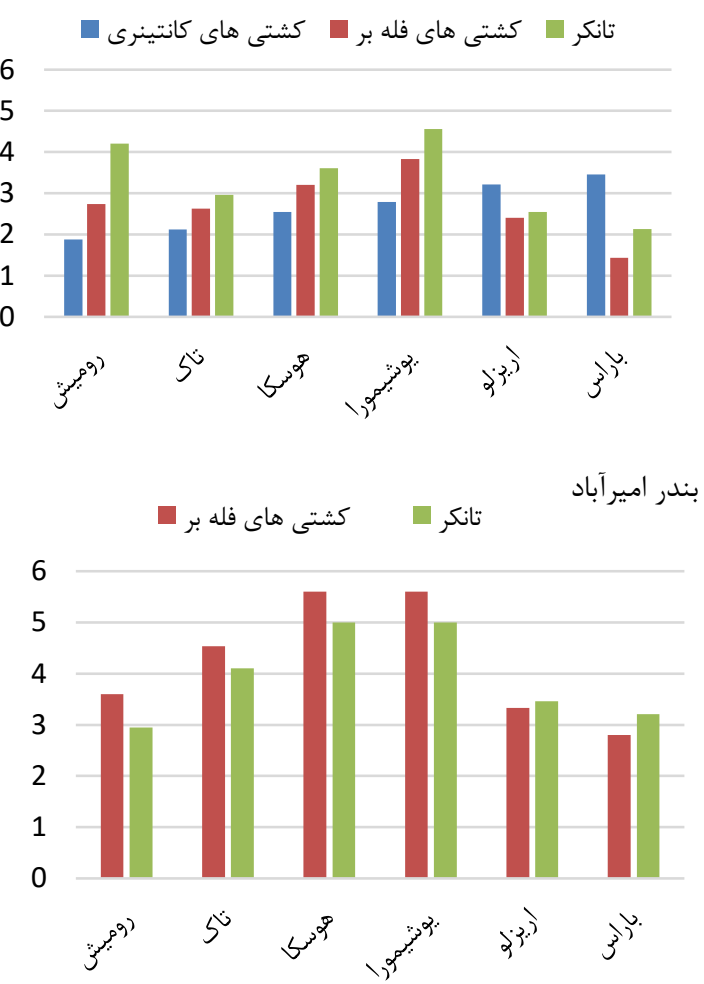

بندر بوشهر

| تانكر || : كشتى هاى فله بر || كشتى هاى كانتينرى

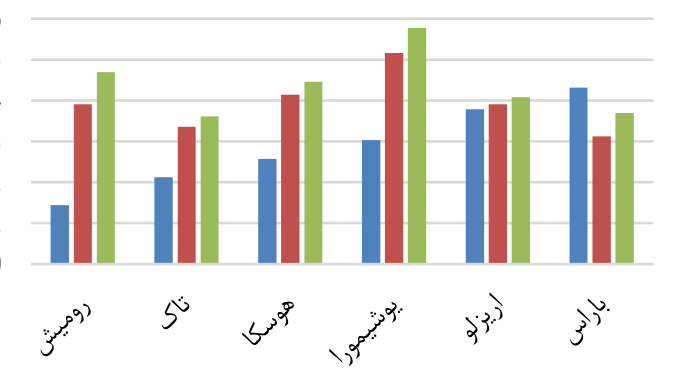

بندر شهيد بهشتى- هابهار

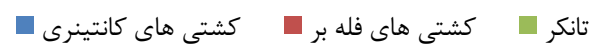

6

5

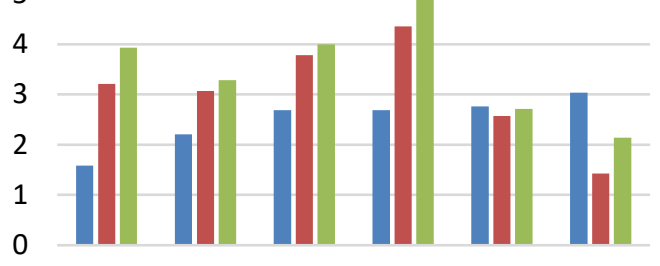

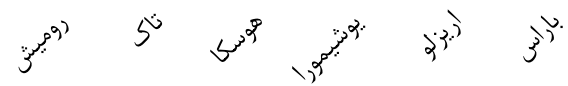

شكل ^- مقادير اسكوات بر حسب درصد از آبخور شناور طرح در سرعت ^ كره دريايى به تفكيك بنادر مورد مطالعه

مذكور بودهاند، آيينامه يِيانك به عنوان مناسبترين آييننامه كه

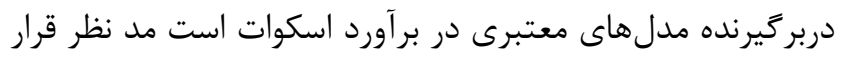

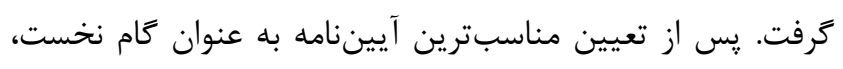

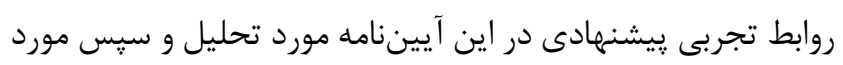

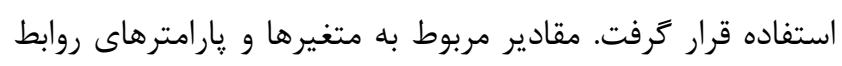

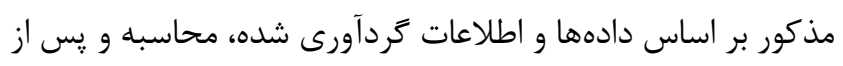

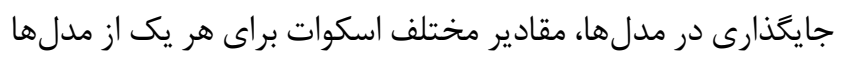

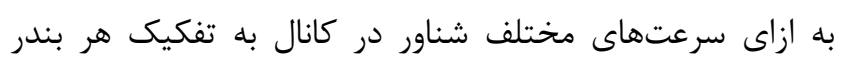

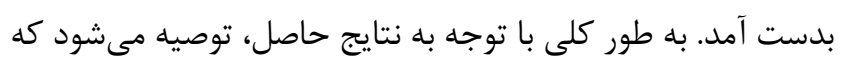

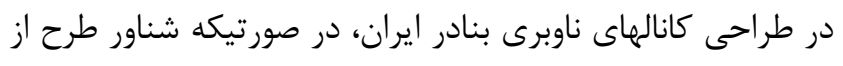

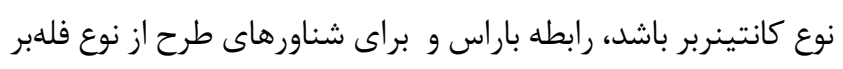

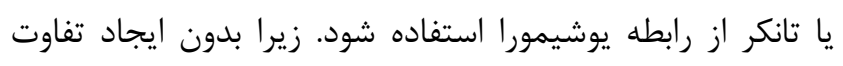
جشمخير در هزينههاى لايروبى، نتيجه قابل اطمينانترى ران را ارائه

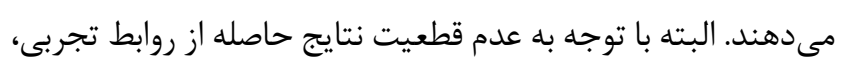

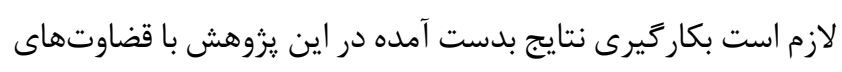
مهندسى نيز همراه باشد.
نتايج بررسى مقادير اسكوات حاصل از روابط مختلف براى انواع

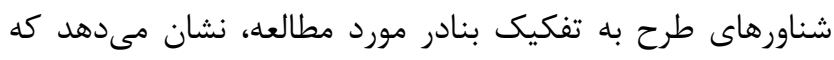

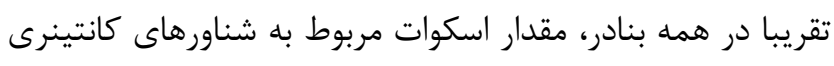

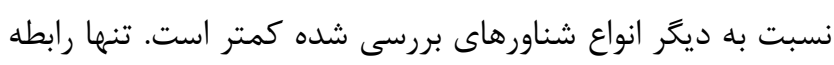

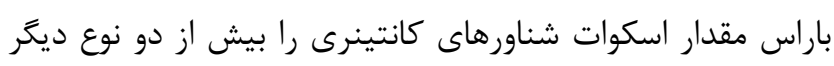

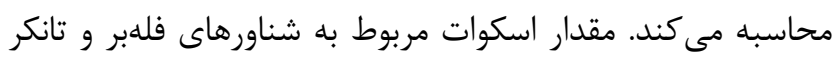

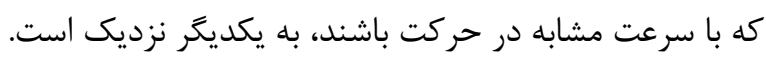

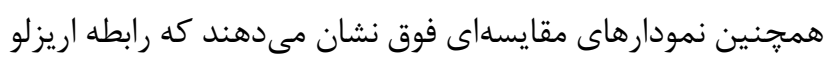

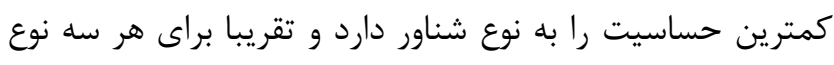

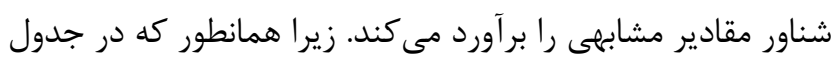

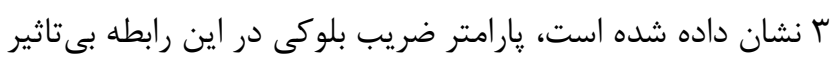

\section{9- جمعبندى و ييشنهادات}

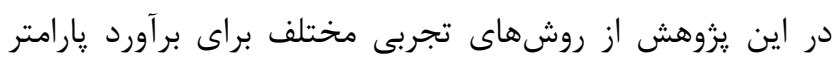

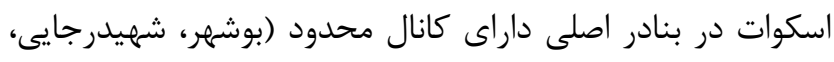

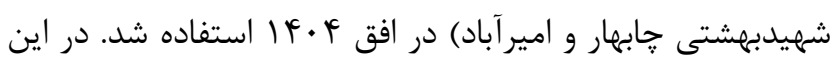

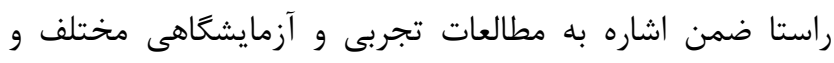
همجنين آيينامههاى معتبر در اين زمينه كه منتج از مطارئ مطالعات مختلف 
Proceedings 8th Symposium on Naval Hydrodynamics, 1970.

[5] PIANC, "“Approach Channels: A Guide for Design," Final Report of the Joint PIANC-IAPH Working Group II-30 in cooperation with IMPA and IALA, Brussels, 1997.

[6] J. Hooft, "The behaviour of a ship in head waves at restricted water depths," International Ship Building Progress, vol. 11, 1974.

[7] Beck, R.F; Newman, J.N., Tuck, E.O. , "Hydrodynamic Forces on Ships in Dredged Channels.," Journal of Ship Research, vol. 9, no. 03, 1975.

[8] O. Huuska, "On the evaluation of underkeel clearances in finnish waterways," Helsinki University of Technology, Ship Hydromechanics Laboratory, Otaniemi, Finland, 1976.

[9] Eryuzlu.N. E. ; Hausser.R, "Experimental investigations into some aspects of large Ships Navigation in restricted Waterways," Proc. Symp. Asp. Navi. Const., vol. 2, 1978.

[10] Eryuzlu, N.E; Cao, Y.L., D'agnolo, F. , "Underkeel Requirements for Large Vessels in Shallow Waterways," in Proceedings 28th International Navigation Congress, PIANC, Spain, 1994.

[11] T .\& .PMO“ ,Iranian Marine Structures and Ports Design guideline ",PBO, Tehran, 1385.

[12] PMO“,Coastal Structures Design Instructions", PBO, Tehran, 1392.

[13] "Technical Standards and Commentaries for port and harbour facilities," The Oveseas costal area developement institute, JAPAN, 2002.

[14] "Maritime works - Part 1-1: General-Code of practice for planning and design for operations," BSI Standards , 2013.

[15] Local statistics of Port and Maritime Organization, Sistan and Baluchestan Province Branch, 1398

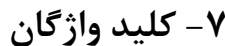

1. Sinkage

2. Change in Trim

3. Tuck and Taylor

4. Dand \& Ferguson

5. Hooft

6. Beck et al

7. Huuska

8. Eryuzlu and Hausser

9. Barrass

10. Römisch

11. Millward

12. Ankudinov

13. Daggett

14. MARSIM, Maritime Simulation and Ship Manoeuvrability

15. Midpoint Sinkage

16. Vessel Trim

17. Lawrence

18. BAW (Bundesanstalt für Wasserbau) Laboratory

19. McTaggart

20. Harbor Approach Channels Design Guidelines

21. Permanent International Association of Navigation Congresses

22. The International Association of Ports and Harbors

23. The International Association of Marine Aids to Navigation and Lighthouse Authorities

24. 1 International Maritime Pilots' Association

25. The Overseas Coastal Area Development Institute of Japan

26. Keel clearance

27. Hull sinking

28. BSI Group

29. Block Coefficient $\left(C_{b}\right)$

30. Depth Froude Number

31. Dead Weight Tonnage (DWT)

32. Length between perpendiculars $\left(\mathrm{L}_{\mathrm{pp}}\right)$

[1] PIANC, "Harbour Approach Channels Design Guidelines," 2014.

[2] B. Barrass, Ship Squat and Interaction, UK: Withersby Publishing \& Seamanship, 2009.

[3] E. Tuck, "Shallow Water Flows Past Slender Bodies," Fluid Mechanics, vol. 26, no. 1, pp. 8195, 1966.

[4] Tuck, E.O;Taylor, P.J, "Shallow Water Problems in Ship Hydrodynamics," in 